STRUCTURAL SCIENCE CRYSTAL ENGINEERING MATERIALS

ISSN 2052-5206

Received 8 January 2020

Accepted 8 July 2020

Edited by J. Lipkowski, Polish Academy of Sciences, Poland

Keywords: solvates; high pressure; crystallization; polymorphs; phase transitions.

CCDC references: $1972145 ; 1972146$; 1972147; 1972148; 1972149; 1972150; $1972151 ; 1972152 ; 1972153 ; 1972154$; 1972155; 1972156; 1972157; 1972158; 1972159; 1972160; 1972161; 1972162; $1972163 ; 1972164 ; 1972165 ; 1972166$; $1972167 ; 1972168 ; 1972169 ; 1972170$

Supporting information: this article has supporting information at journals.iucr.org/b

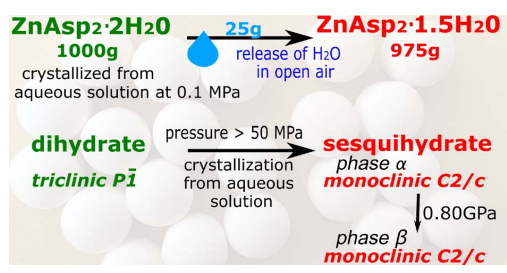

\section{High-pressure preference for reduced water content in porous zinc aspartate hydrates}

\author{
Kinga Roszak and Andrzej Katrusiak* \\ Faculty of Chemistry, Adam Mickiewicz University, ul. Uniwersytetu Poznańskiego 8, Poznań 61-614, Poland. \\ ${ }^{*}$ Correspondence e-mail: katran@amu.edu.pl
}

The zinc aspartate $\left(\mathrm{ZnAsp}_{2}\right)$ complex, a common dietary supplement, preferentially crystallizes as the dihydrate $\left(\mathrm{ZnAsp}_{2} \cdot 2 \mathrm{H}_{2} \mathrm{O}\right)$ from aqueous solution. Under normal conditions the dihydrate easily transforms into the sesquihydrate $\left(\mathrm{ZnAsp}_{2} \cdot 1.5 \mathrm{H}_{2} \mathrm{O}\right)$. The dihydrate crystal structure is triclinic, space group $P \overline{1}$, and the sesquihydrate is monoclinic, space group $C 2 / c$. However, their structures are closely related and similarly consist of zinc aspartate ribbons parallel to pores accommodating water molecules. These porous structures can breathe water molecules in and out depending on the temperature and air humidity. High pressure above $50 \mathrm{MPa}$ favours the sesquihydrate, as shown by recrystallizations under pressure and compressibility measured by single-crystal X-ray diffraction up to $4 \mathrm{GPa}$. This preference is explained by the reduced volume of the sesquihydrate and water compressed separately, compared with the dihydrate. The sesquihydrate undergoes an isostructural phase transition when the voids collapse at $0.8 \mathrm{GPa}$, whereas no phase transitions occur in the dihydrate, because its pores are supported by increased water content.

\section{Introduction}

Zinc plays a key role in the human body as a cofactor of numerous enzymes and it is therefore often included in dietary supplements and medicines for various illnesses (Shankar \& Prasad, 1998; Haase et al., 2008; Roohani et al., 2013; Azeem et al., 2019). Zinc aspartate hydrate $\left(\mathrm{ZnAsp}_{2} \cdot n \mathrm{H}_{2} \mathrm{O}\right.$, Asp denotes the aspartate anion; Fig. 1) is often used as a source of zinc cations and aspartate amino acids. This racemic complex preferentially crystallizes in the form of hydrates but their structures have not been determined so far.

We have established that crystallization from an aqueous solution under normal conditions yields the dihydrate, $\mathrm{ZnAsp} 2 \cdot 2 \mathrm{H}_{2} \mathrm{O}$, whereas high-pressure crystallization yields the sesquihydrate, $\mathrm{ZnAsp}_{2} \cdot 1.5 \mathrm{H}_{2} \mathrm{O}$. The structures of both these hydrates are determined here, and the mechanism favouring reduced water content at high pressure is described.

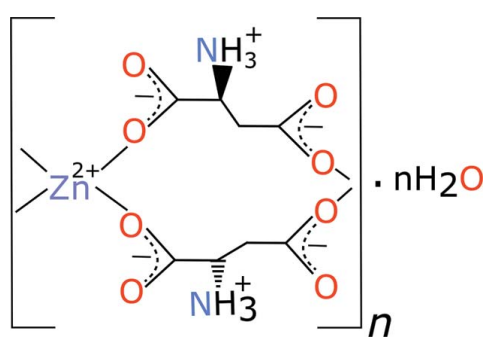

Figure 1

The structural formula of zinc aspartate hydrate, $\mathrm{ZnAsp}_{2} \cdot n \mathrm{H}_{2} \mathrm{O}$. 
The effect of high pressure on the hydration of various organic compounds, such as methane (Kevenvolden, 1995), thiourea (Figuiere et al., 1975; Tomkowiak et al., 2013; Tomkowiak \& Katrusiak, 2018), 1,4-diazabicyclo[2.2.2]octane hydroiodide (dabcoHI, Olejniczak \& Katrusiak, 2010), 1,4diazabicyclo[2.2.2] octane dibromide (dabco2HBr, Andrzejewski et al., 2011), 5,6-dimethylbenzimidazole (Zieliński \& Katrusiak, 2015) and 4,4'-bipyridinium perchlorate (Anioła \& Katrusiak, 2017), and minerals (Van Valkenburg et al., 1971), is well documented in the literature. However, in most cases high pressure increases the water content in a crystal structure, and exceptions are rare. For example, the hydrate $\mathrm{Y}_{2}\left(\mathrm{C}_{2} \mathrm{O}_{4}\right)_{3} \cdot 10 \mathrm{H}_{2} \mathrm{O}$ reduces its water content at $1 \mathrm{GPa}$ to $\mathrm{Y}_{2}\left(\mathrm{C}_{2} \mathrm{O}_{4}\right)_{3} \cdot 6 \mathrm{H}_{2} \mathrm{O}$ (Zakharov et al., 2017), the dehydration of phosphatidylinositol bilayers was postulated above $0.7 \mathrm{GPa}$ based on IR spectroscopy (Carrier \& Wong, 1996), and the decomposition of orthoboric acid with the release of water at about 2 GPa was reported by Kuznetsov et al. (2006). We also noted that pressures above $1 \mathrm{GPa}$ prevent the formation of hydrates of thiourea (Figuiere et al., 1975; Tomkowiak et al., 2013; Tomkowiak \& Katrusiak, 2018) and at pressures above $8 \mathrm{GPa}$ no methane hydrates are formed (Kevenvolden, 1995). Presently, we have established that the porous crystals of $\mathrm{ZnAsp}_{2} \cdot n \mathrm{H}_{2} \mathrm{O}$ display structural features connected to their water content. These features can be conveniently studied and modelled for this compound. We show that sesquihydrate $\mathrm{ZnAsp}_{2} \cdot n \mathrm{H}_{2} \mathrm{O}$ can be employed as an internal component (in tablets) to protect active pharmaceutical ingredients (APIs) from the effects of humidity.

High-pressure studies on APIs increased the number of efficient methods for obtaining new polymorphs (Zakharov et al., 2016a,b; Neumann et al., 2015; Boldyreva et al., 2002; Boldyreva, 2003; Patyk-Kaźmierczak \& Kaźmierczak, 2020; Fabbiani \& Pulham, 2006; Oswald et al., 2010) and solvates (Fabbiani et al., 2003; 2014). Solvated APIs can be sensitive to the pressure employed in the process of formulation, for example in pressing tablets. High-pressure studies also provide a broader perspective for understanding the thermodynamic transformations of APIs.

\section{Experimental}

We performed high-pressure experiments either by gradually compressing a single crystal in a diamond anvil cell (DAC), or by high-pressure recrystallization and growing single crystals in isothermal and isochoric conditions from aqueous solutions in situ in the DAC. Experimental parameters and crystal data are listed in Table 1, and in Tables S1 and S2 in the supporting information. High-pressure experiments were performed in a Merrill-Bassett DAC (Merrill \& Bassett, 1974), modified by mounting the anvils directly on steel backing plates with conical windows (Katrusiak, 2008). The form of the crystals grown was determined by single-crystal X-ray diffraction (Table 1, and Tables S1 and S2 in the supporting information). All isochoric high-pressure recrystallizations yielded the sesquihydrate, $\mathrm{ZnAsp}_{2} \cdot 1.5 \mathrm{H}_{2} \mathrm{O}$. Its growth process is illu-
Table 1

Selected crystal data for $\mathrm{ZnAsp}_{2} \cdot 1.5 \mathrm{H}_{2} \mathrm{O}$ and $\mathrm{ZnAsp}_{2} \cdot 2 \mathrm{H}_{2} \mathrm{O}$, all at $296 \mathrm{~K}$ (see also Tables S1 and S2 in the supporting information).

\begin{tabular}{lllll}
\hline & $\mathrm{ZnAsp}_{2} \cdot 1.5 \mathrm{H}_{2} \mathrm{O}$ & $\mathrm{ZnAsp}_{2} \cdot 2 \mathrm{H}_{2} \mathrm{O}$ \\
\hline Pressure (GPa) & 0.0001 & 3.92 & 0.0001 & 4.02 \\
Crystal system & Monoclinic & Monoclinic & Triclinic & Triclinic \\
Space group & $C 2 / c$ & $C 2 / c$ & $P \overline{1}$ & $P \overline{1}$ \\
$a(\AA)$ & $16.2789(3)$ & $15.550(3)$ & $8.7873(3)$ & $8.343(7)$ \\
$b(\AA)$ & $10.7307(2)$ & $10.2262(7)$ & $9.5061(3)$ & $8.947(6)$ \\
$c(\AA)$ & $14.5393(3)$ & $13.966(1)$ & $9.8114(3)$ & $9.537(3)$ \\
$\alpha\left({ }^{\circ}\right)$ & 90 & 90 & $111.784(3)$ & $110.02(4)$ \\
$\beta\left({ }^{\circ}\right)$ & $93.017(2)$ & $92.62(3)$ & $105.625(3)$ & $104.76(4)$ \\
$\gamma\left({ }^{\circ}\right)$ & 90 & 90 & $107.721(3)$ & $109.16(7)$ \\
$V\left(\AA^{3}\right)$ & $2536.26(8)$ & $2219(4)$ & $653.73(4)$ & $575.2(7)$ \\
$Z / Z^{\prime}$ & $4 / 0.5$ & $4 / 0.5$ & $1 / 0.5$ & $1 / 0.5$ \\
$D_{x}\left(\mathrm{~g} \mathrm{~cm}^{-3}\right)$ & 1.868 & 2.135 & 1.857 & 2.111 \\
\hline
\end{tabular}

strated in Fig. 2 (see also Fig. S1 in the supporting information).

The sesquihydrate could be recovered from the DAC and no visible changes occurred to the samples exposed to air for weeks. On the other hand, the initially crystallized dihydrate powder kept in a thermally closed plastic bag for two months fully transformed into the sesquihydrate. This indicates that the dihydrate is stable only when submerged in water and in highly humid environments.

The compression of $\mathrm{ZnAsp}_{2} \cdot 1.5 \mathrm{H}_{2} \mathrm{O}$ and $\mathrm{ZnAsp}_{2} \cdot 2 \mathrm{H}_{2} \mathrm{O}$ crystals was determined for the samples mounted in the DAC. The gasket was made of $0.2 \mathrm{~mm}$ thick Inconel foil and the initial diameter of the spark-eroded hole was $0.45 \mathrm{~mm}$.
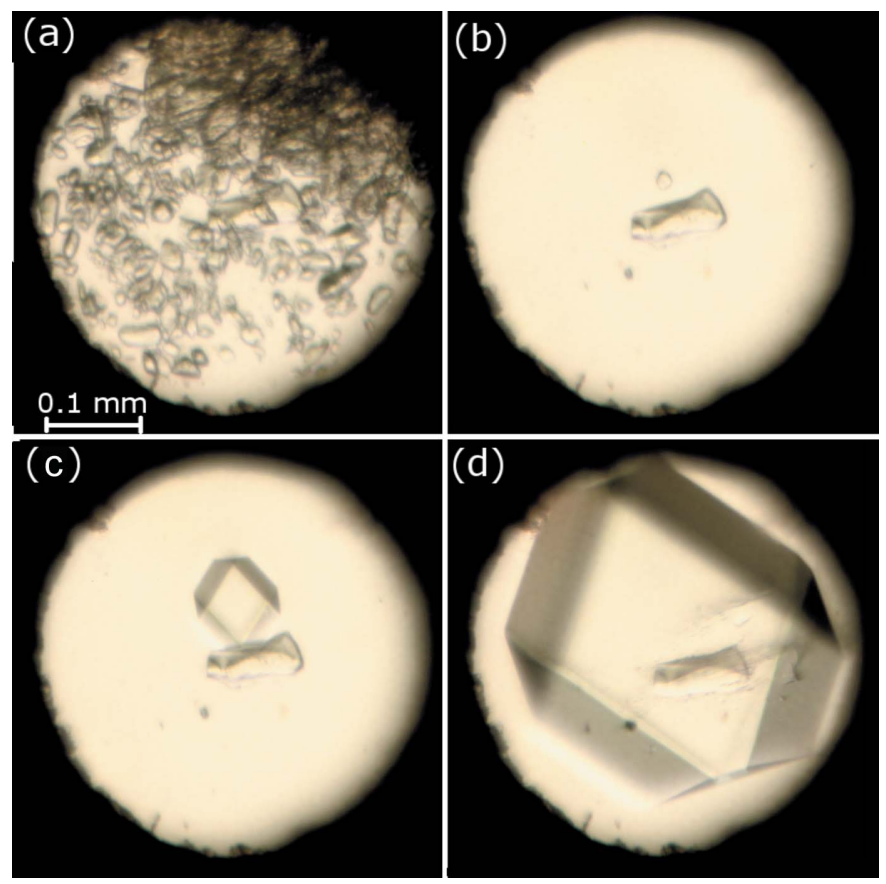

Figure 2

The stages of $\mathrm{ZnAsp}_{2} \cdot 1.5 \mathrm{H}_{2} \mathrm{O}$ single-crystal growth from aqueous solution under isochoric conditions in the DAC chamber. (a) Spontaneous powder precipitation at $433 \mathrm{~K}$, and one seed at (b) $443 \mathrm{~K}$, (c) $343 \mathrm{~K}$ and $(d) 0.49 \mathrm{GPa} / 296 \mathrm{~K}$. The ruby chip for pressure calibration lies near the middle of the chamber. 
Glycerine was used as a hydrostatic medium. The pressure in the DAC was calibrated before and after each diffraction measurement by the ruby fluorescence method (Piermarini et al., 1975; Mao et al., 1986) using a Photon Control Inc. spectrometer of enhanced resolution, affording an accuracy of $0.02 \mathrm{GPa}$.

Single-crystal high-pressure data were measured on a KUMA KM4 CCD diffractometer according to the procedure described previously (Budzianowski \& Katrusiak, 2004). The CrysAlisPro software (Rigaku Oxford Diffraction, 2015) was used for diffraction data collection and preliminary reduction. Reflections that overlapped with diamond reflections were eliminated, and corrections for the DAC and sample absorption and for beam shadowing by the gasket were applied. Using OLEX2 (Dolomanov et al., 2009), the crystal structures were solved by intrinsic phasing with SHELXT (Sheldrick, $2015 a)$ and refined by least-squares with the program SHELXL (Sheldrick, 2015b). The ambient-pressure structures were used as the starting models for refinement of the highpressure data. Anisotropic displacement factors were generally applied for non-hydrogen atoms. C- and N-bound $\mathrm{H}$ atoms were located from the molecular geometry (assuming distances of $\mathrm{C}-\mathrm{H}=0.97 \AA$ for methylene, $\mathrm{C}-\mathrm{H}=0.98 \AA$ for methine and $\mathrm{N}-\mathrm{H}=0.89 \AA$ for $\mathrm{NH}_{3}$ ). The water $\mathrm{H}$ atoms were located from difference Fourier maps and then the positions of $\mathrm{H}_{2} \mathrm{O}$ were refined as rigid units. The $U_{\text {iso }}$ values of the $\mathrm{H}$ atoms were constrained to 1.2 times the $U_{\text {eq }}$ of their carrier atoms. Structural drawings were prepared using the program Mercury CSD 3.3 (Macrae et al., 2020). A total of 26 different data sets were collected, at 15 different pressures for the sesquihydrate and 11 different pressures for the dihydrate. The crystal data have been deposited in the Cambridge Structural Database (CSD; Groom et al., 2016) as supplementary publications (CSD 1972145-1972170).

Powder X-ray diffraction (XRPD) patterns were recorded using a Bruker AXS D8 Advance diffractometer, equipped with a sealed X-ray tube, a Johansson monochromator selecting $\mathrm{Cu} K \alpha_{1}$ radiation $(\lambda=1.54060 \AA)$ and a LynxEye detector. The samples were gently pressed into a flat round cuvette of about $0.4 \mathrm{~cm}^{3}$ in volume. The cuvette was rotated during the measurements, performed in $\theta$ steps of $0.02^{\circ}$ and in the $\theta-2 \theta$ mode.

Thermogravimetric (TG) and differential scanning calorimetry (DSC) analyses were performed for $18.2 \mathrm{mg}$ of ZnAsp $2 \cdot 2 \mathrm{H}_{2} \mathrm{O}$ in an $\mathrm{N}_{2}$ atmosphere on a Setsys 1200 Setaram instrument between $293 \mathrm{~K}$ and $573 \mathrm{~K}$ at a scan speed of $5 \mathrm{~K} \mathrm{~min}^{-1}$.

\section{Results and discussion}

The compressed crystals of $\mathrm{ZnAsp}_{2} \cdot 1.5 \mathrm{H}_{2} \mathrm{O}$ and $\mathrm{ZnAsp} 2 \cdot 2 \mathrm{H}_{2} \mathrm{O}$ retain the ambient-pressure monoclinic symmetry of space group $C 2 / c$ and triclinic symmetry of space group $P \overline{1}$, respectively, up to $4 \mathrm{GPa}$ at least (Table 1, Fig. 3, Figs. S2 and S3).

Although seemingly very different (Table 1 ), the crystal structures of $\mathrm{ZnAsp}_{2}$ dihydrate and sesquihydrate are strik-
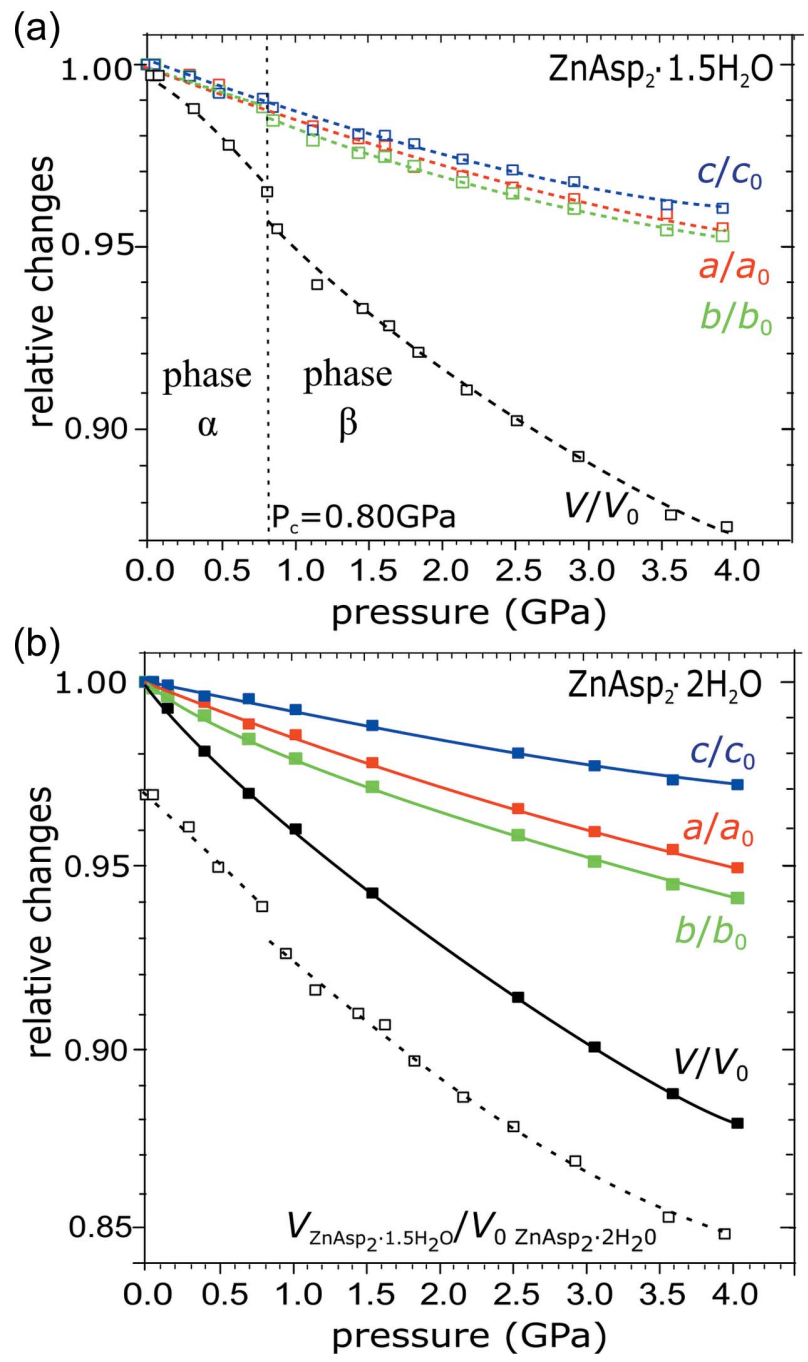

Figure 3

Unit-cell dimensions of $(a) \mathrm{ZnAsp}_{2} \cdot 1.5 \mathrm{H}_{2} \mathrm{O}$ (open symbols, dashed lines) and $(b) \mathrm{ZnAsp}_{2} \cdot 2 \mathrm{H}_{2} \mathrm{O}$ (solid symbols and lines), relative to their values at $296 \mathrm{~K} / 0.1 \mathrm{MPa}$, as a function of pressure. The magnitudes of the unit-cell parameters, including the angular dimensions, are plotted in Figs. S2 and S3. The vertical dashed line in panel $(a)$ indicates the phase transition in $\mathrm{ZnAsp}_{2} \cdot 1.5 \mathrm{H}_{2} \mathrm{O}$ (see also Fig. S6). The open black symbols in panel (b) show the volume compression in $\mathrm{ZnAsp}_{2} \cdot 1.5 \mathrm{H}_{2} \mathrm{O}$ relative to the volume of $\mathrm{ZnAsp}_{2} \cdot 2 \mathrm{H}_{2} \mathrm{O}$ at $0.1 \mathrm{MPa}$.

ingly similar. Their Bravais lattices can be transformed into one another through the following matrix $\mathbf{M}$ :

$$
\left(\begin{array}{l}
\mathbf{a}_{\mathrm{m}} \\
\mathbf{b}_{\mathrm{m}} \\
\mathbf{c}_{\mathrm{m}}
\end{array}\right)=\left(\begin{array}{ccc}
1 & 1 & 2 \\
1 & 1 & 0 \\
-1 & 1 & 0
\end{array}\right)\left(\begin{array}{l}
\mathbf{a}_{\mathrm{t}} \\
\mathbf{b}_{\mathrm{t}} \\
\mathbf{c}_{\mathrm{t}}
\end{array}\right),
$$

where the subscripts $\mathrm{m}$ and $\mathrm{t}$ refer to the (pseudo)monoclinic $C$ lattice of $\left(\mathrm{ZnAsp}_{2} \cdot 1.5 \mathrm{H}_{2} \mathrm{O}\right)$ and the triclinic $P$ lattice of $\left(\mathrm{ZnAsp}_{2} \cdot 2 \mathrm{H}_{2} \mathrm{O}\right)$, respectively. The reverse matrix $\mathbf{M}^{-1}$ transforms the lattice $C_{\mathrm{m}}$ into $P_{\mathrm{t}}$ :

$$
\left(\begin{array}{l}
\mathbf{a}_{\mathrm{t}} \\
\mathbf{b}_{\mathrm{t}} \\
\mathbf{c}_{\mathrm{t}}
\end{array}\right)=\left(\begin{array}{ccc}
0 & 0.5 & -0.5 \\
0 & 0.5 & 0.5 \\
0.5 & -0.5 & 0
\end{array}\right)\left(\begin{array}{l}
\mathbf{a}_{\mathrm{m}} \\
\mathbf{b}_{\mathrm{m}} \\
\mathbf{c}_{\mathrm{m}}
\end{array}\right) .
$$

Thus the triclinic $P$ unit cell of $\mathrm{ZnAsp}_{2} \cdot 2 \mathrm{H}_{2} \mathrm{O}$ at $0.1 \mathrm{MPa}$ can be represented as the pseudo-monoclinic unit cell $C$, having 
the following dimensions: $a=16.445 \AA, b=10.804 \AA, c=$ $14.780 \AA, \alpha=85.28^{\circ}, \beta=92.27^{\circ}, \gamma=89.66^{\circ}$, which are similar to the unit cell of $\mathrm{ZnAsp}_{2} \cdot 1.5 \mathrm{H}_{2} \mathrm{O}$ (Table 1). According to the unit-cell angles of the pseudo-monoclinic $C$ lattice of $\mathrm{ZnAsp} 2 \cdot 2 \mathrm{H}_{2} \mathrm{O}$ (Fig. S3), with increasing pressure this triclinic structure only hardly, within about $0.5^{\circ}$, changes its distortions from the monoclinic symmetry.

Thus the sorption of water molecules into the $\mathrm{ZnAsp}_{2} \cdot n \mathrm{H}_{2} \mathrm{O}$ framework results in its transformation, changing the symmetry of the crystal structure. It is characteristic that the monoclinic symmetry of space group $C 2 / c$ of $\mathrm{ZnAsp}_{2} \cdot 1.5 \mathrm{H}_{2} \mathrm{O}$ is reduced to the triclinic space group $P \overline{1}$ of $\mathrm{ZnAsp} 2 \cdot 2 \mathrm{H}_{2} \mathrm{O}$ after the water content increases. This inverse sorption-symmetry relation is surprising, as according to our survey an increased water content of the pores either increases or preserves the crystal symmetry. For example, the spacegroup symmetry $R 3$ of anhydrate stepanovite polymorph ST1d increases to space group $R 3 c$ for stepanovite $\left[\mathrm{Mg}\left(\mathrm{H}_{2} \mathrm{O}\right)_{6}\right]\left[\mathrm{NaFe}\left(\mathrm{C}_{2} \mathrm{O}_{4}\right)_{3}\right] \cdot 3 \mathrm{H}_{2} \mathrm{O}$; for the polymorph ST2d its anhydrate has space-group symmetry $P 3$ and after hydration the symmetry increases to $P 3 c$ (Huskić et al., 2019); the space- group symmetries $P 2_{1} / n$ and $P \overline{1}$ of lithium acetate $\left(\mathrm{LiC}_{2} \mathrm{H}_{3} \mathrm{O}_{2}\right)$ polymorphs increase to $\mathrm{Cmmm}$ for the dihydrate; and space group $P \overline{1}$ of lithium acetate monohydrate, $4\left(\mathrm{LiC}_{2} \mathrm{H}_{3} \mathrm{O}_{2}\right) \cdot \mathrm{H}_{2} \mathrm{O}$, increases to $P 2_{1} / c$ for the tetrahydrate $4\left(\mathrm{LiC}_{2} \mathrm{H}_{3} \mathrm{O}_{2}\right) \cdot 4 \mathrm{H}_{2} \mathrm{O}$ (Martínez-Casado et al., 2011).

We have established that $\mathrm{ZnAsp} 2$ preferentially crystallizes as the dihydrate when crystallized from water solution under normal conditions ( $298 \mathrm{~K}, 0.1 \mathrm{MPa})$. The dihydrate crystals are triclinic (Table 1). In these crystal structures the water molecules are located in channel pores and do not participate in the $\mathrm{Zn}^{2+}$ coordination. In $\mathrm{ZnAsp}_{2} \cdot 2 \mathrm{H}_{2} \mathrm{O}$ the $\mathrm{Zn}^{2+}$ cation is coordinated by four carboxylate oxygens of four Asp anions, as illustrated in Fig. 4. Each Asp participates in coordinating two $\mathrm{Zn}^{2+}$ cations, closing cyclamers of the form $-\mathrm{Zn}^{2+}-\mathrm{Asp}-$ $\mathrm{Zn}^{2+}-\mathrm{Asp}-$, and these are combined into chains extending along the [010] crystal direction. In $\mathrm{ZnAsp}_{2} \cdot 1.5 \mathrm{H}_{2} \mathrm{O}$ the $\mathrm{Zn}^{2+}$ cation is coordinated in the same way as in $\mathrm{ZnAsp}_{2} \cdot 2 \mathrm{H}_{2} \mathrm{O}$. The $\mathrm{ZnAsp}_{2}$ ribbons are very similar in the dihydrate and sesquihydrate, as shown in Fig. 4. The conformation of the Asp units and their coordination of $\mathrm{Zn}^{2+}$ is consistent to within a few degrees for the corresponding torsion angles (Fig. S4).

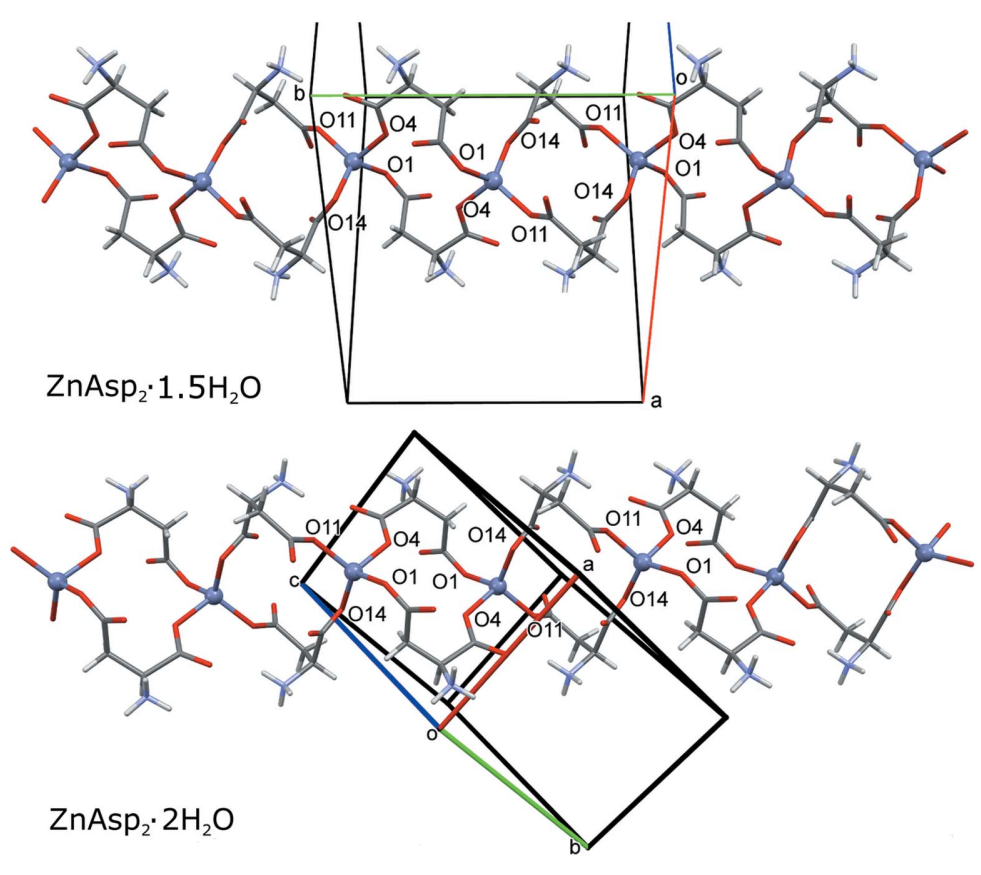

(a)

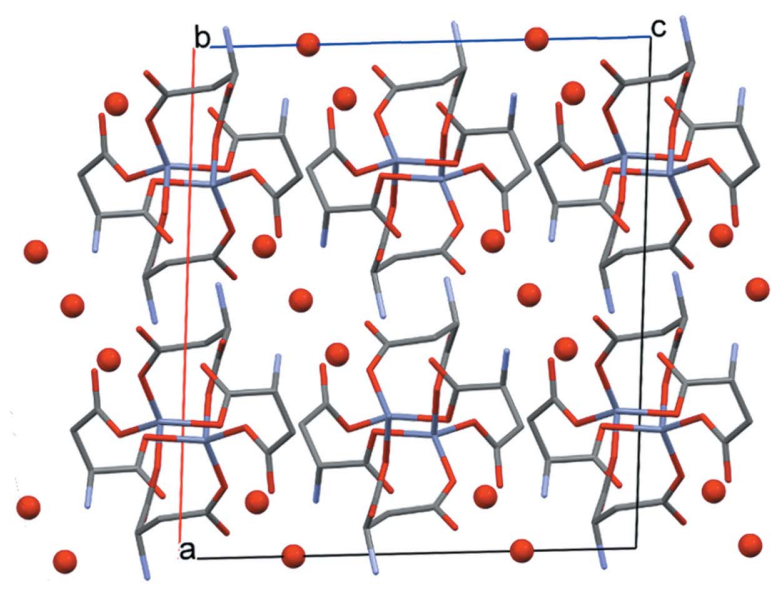

$\mathrm{ZnAsp}_{2} \cdot 1.5 \mathrm{H}_{2} \mathrm{O}$

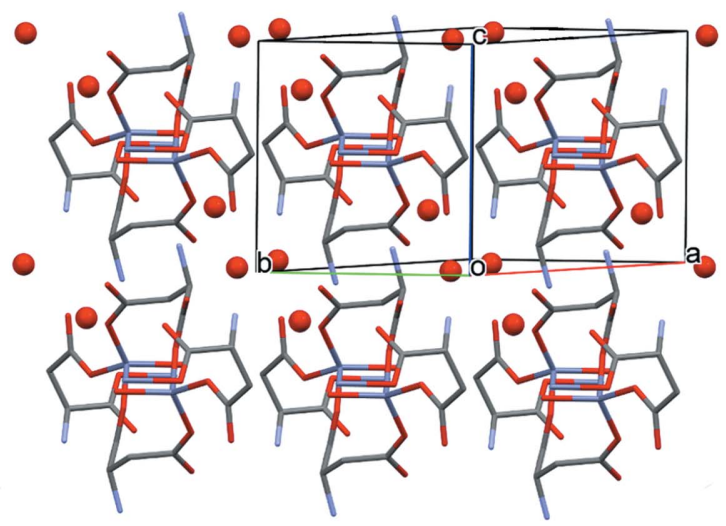

$\mathrm{ZnAsp} \cdot 2 \mathrm{H}_{2} \mathrm{O}$

Figure 4

(a) Autostereographic projections (Katrusiak, 2001) of the ribbons formed by the $\mathrm{Zn}$ cations four-fold coordinated by Asp anions in $\mathrm{ZnAsp} \cdot 1.5 \mathrm{H}_{2} \mathrm{O}$ and $\mathrm{ZnAsp} 2 \cdot 2 \mathrm{H}_{2} \mathrm{O}$. Water molecules have been omitted for clarity. (b) The $\mathrm{ZnAsp}_{2} \cdot 1.5 \mathrm{H}_{2} \mathrm{O}$ and $\mathrm{ZnAsp}_{2} \cdot 2 \mathrm{H}_{2} \mathrm{O}$ structures projected down the $\mathrm{ZnAsp}{ }_{2}$ ribbons. Water molecules are represented as red balls. $\mathrm{H}$ atoms have been omitted for clarity. 
It is a common feature of both $\mathrm{ZnAsp}_{2} \cdot 1 \cdot 5 \mathrm{H}_{2} \mathrm{O}$ and $\mathrm{ZnAsp} 2 \cdot 2 \mathrm{H}_{2} \mathrm{O}$ that all water molecules interact through $\mathrm{O}-\mathrm{H} \cdots \mathrm{O}$ and $\mathrm{N}-\mathrm{H} \cdots \mathrm{O}$ hydrogen bonds, but no water molecules participate in $\mathrm{Zn}$ coordination. There are very similar intramolecular $\mathrm{N} 13-\mathrm{H} 13 C \ldots \mathrm{O} 11$ and $\mathrm{N} 3-$ $\mathrm{H} 3 A \cdots \mathrm{O} 2$ hydrogen bonds in both $\mathrm{ZnAsp}_{2} \cdot 1.5 \mathrm{H}_{2} \mathrm{O}$ and $\mathrm{ZnAsp} \cdot 2 \mathrm{H}_{2} \mathrm{O}$. Almost all of the hydrogen bonds involve water molecules. The hydrogen bonds to $\mathrm{H}_{2} \mathrm{O}$ molecules are $\mathrm{O} 1 W-\mathrm{H} 1 W B \cdots \mathrm{O} 14, \quad \mathrm{O} 1 W-\mathrm{H} 1 W A \cdots \mathrm{O} 2, \quad \mathrm{O} 2 W-$ $\mathrm{H} 2 W B \cdots \mathrm{O} 12$ and $\mathrm{N} 3-\mathrm{H} 3 C \cdots \mathrm{O} 1 W$. Two other hydrogen bonds are $\mathrm{N} 13-\mathrm{H} 13 B \cdots \mathrm{O} 2$ and $\mathrm{N} 3-\mathrm{H} 3 B \cdots \mathrm{O} 13$, both present in the $\mathrm{ZnAsp}_{2} \cdot 1.5 \mathrm{H}_{2} \mathrm{O}$ and $\mathrm{ZnAsp}_{2} \cdot 2 \mathrm{H}_{2} \mathrm{O}$ structures. The $\mathrm{O} 2 W-\mathrm{H} 2 W A \cdots \mathrm{O} 1 W$ bond between two water molecules is formed only in $\mathrm{ZnAsp}_{2} \cdot 2 \mathrm{H}_{2} \mathrm{O}$ (Figs. S5 and S9).

It is remarkable that although $\mathrm{ZnAsp}_{2} \cdot 2 \mathrm{H}_{2} \mathrm{O}$ and $\mathrm{ZnAsp}_{2} \cdot 1.5 \mathrm{H}_{2} \mathrm{O}$ can interconvert one into the other under ambient conditions, each of them can be compressed in glycerine to $4 \mathrm{GPa}$ at least (Fig. 3). However, while the compression of $\mathrm{ZnAsp}_{2} \cdot 2 \mathrm{H}_{2} \mathrm{O}$ is monotonic, in $\mathrm{ZnAsp} \cdot 1.5 \mathrm{H}_{2} \mathrm{O}$ we have noted an anomalous strain at about $0.8 \mathrm{GPa}$. This anomaly is clearly seen in the pressure dependence of the monoclinic angle $\beta$, which initially rises and at $0.8 \mathrm{GPa}$ drops abruptly by $0.1^{\circ}$, and then it continues to drop in a monotonous way it at still higher pressure (Fig. 5). A similar discontinuity is observed in the compression of unitcell parameter $a$ [Fig. 5(b)] and in the volume compression (Fig. 3). It appears that the anomalous 'compression' of the $\beta$ angle in $\mathrm{ZnAsp}_{2} \cdot 1.5 \mathrm{H}_{2} \mathrm{O}$ is a consequence of the directional interactions $-\mathrm{Zn}-\mathrm{O}$ coordination and $\mathrm{O}-\mathrm{H} \cdots \mathrm{O}$ hydrogen

(a)

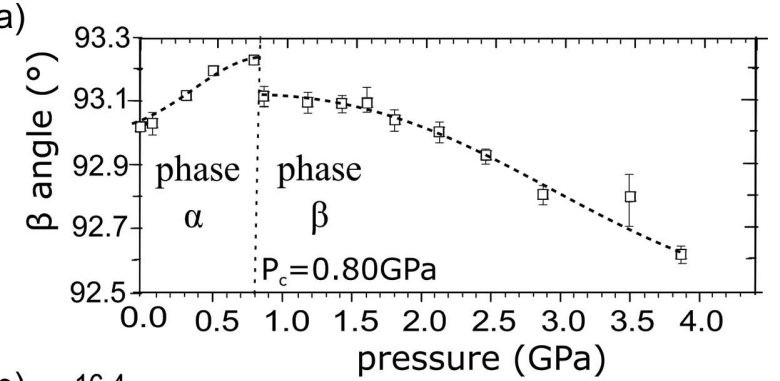

(b)

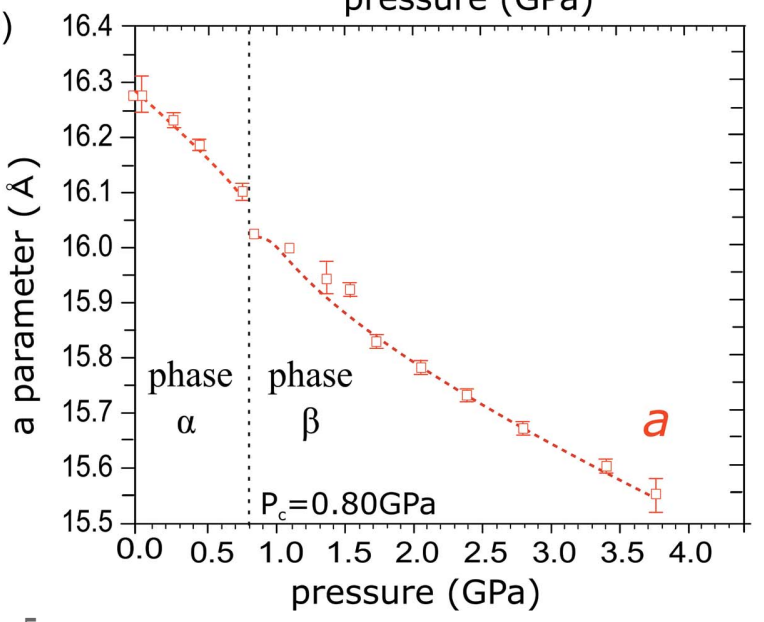

Figure 5

The pressure dependence of $(a)$ angle $\beta$ and (b) parameter $a$ of the unit cell in $\mathrm{ZnAsp}_{2} \cdot 1.5 \mathrm{H}_{2} \mathrm{O}$. The changes in all the unit-cell dimensions are plotted in Fig. S2. bonds - forming the framework in this structure. These directional bonds play a dominant role in the dimensions and elastic properties of the crystal. Owing to this relatively rigid framework, some small voids are present in the crystal under normal conditions. However, above $0.8 \mathrm{GPa}$ the directional bonds yield under the external pressure and the small voids are suppressed. Thus the anomalous compression marks the pressure value at which central forces supported by the external pressure overcome the angular dimensions favoured by the directional interactions, triggering a collapse to a more densely packed structure [Fig. 6(a)]. These two phases of $\mathrm{ZnAsp} \cdot 1.5 \mathrm{H}_{2} \mathrm{O}$ will be further referred to as phases $\alpha$ and $\beta$.

The $\mathrm{ZnAsp}_{2} \cdot 1.5 \mathrm{H}_{2} \mathrm{O}$ structure determined at $0.9 \mathrm{GPa}$ is an average of these phases, as the $\mathrm{X}$-ray diffraction measurement was performed when the sample had partly transformed between phases $\alpha$ and $\beta$. The anomalous compression at $0.8 \mathrm{GPa}$, determined from the unit-cell dimensions, agrees well with the collapse of the pores. Their volume is plotted as a function of pressure in Fig. 6 (note the 'intermediate' volume of the pores at $0.9 \mathrm{GPa}$, due to the averaged structures of phases $\alpha$ and $\beta$, as explained above). According to the X-ray
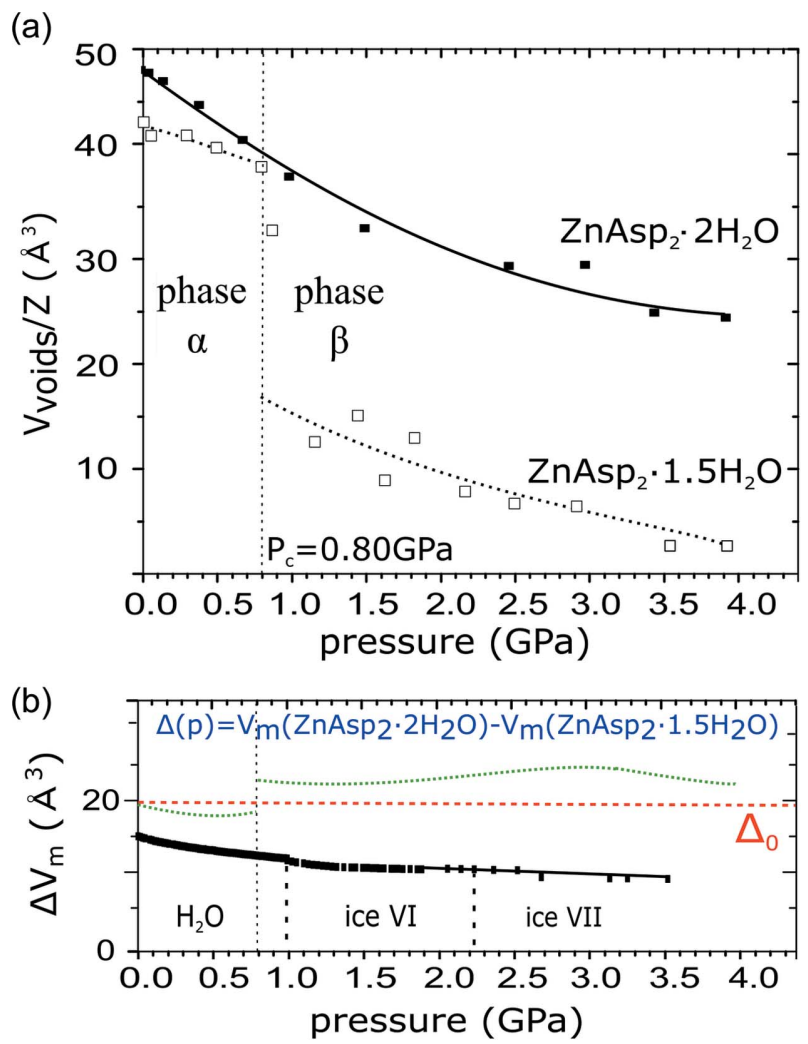

Figure 6

(a) The pressure dependence of the void volume $\left(V_{\text {voids }}\right)$ of ZnAsp $2 \cdot 1.5 \mathrm{H}_{2} \mathrm{O}$ (open symbols, dotted lines) and $\mathrm{ZnAsp}_{2} \cdot 2 \mathrm{H}_{2} \mathrm{O}$ (solid symbols, continuous line) after removing the water molecules from these structures, per one formula unit $\left(V_{\text {voids }} / Z\right)$. The void volume was calculated using the program Mercury (Macrae et al., 2020) with a probing-sphere radius of $1.2 \AA$ and $0.1 \AA$ steps. $(b)$ The molecular volume of water (i.e. one $\mathrm{H}_{2} \mathrm{O}$ molecule in liquid; Bridgman, 1935) and ices VI (Kuhs et al., 1984) and VII (Bezacier et al., 2014) as a function of pressure compared with the difference in molecular volume $\left(V_{\mathrm{m}}=V / Z\right)$ between $\mathrm{ZnAsp}_{2} \cdot 2 \mathrm{H}_{2} \mathrm{O}$ and $\mathrm{ZnAsp}_{2} \cdot 1.5 \mathrm{H}_{2} \mathrm{O}(\Delta V m) . \Delta_{0}$ is this difference at $0.1 \mathrm{MPa}$ (see also Fig. S6). 
diffraction data, the transition at $0.8 \mathrm{GPa}$ does not change the crystal symmetry. Thus it can be classified as an isostructural phase transition, which is quite common for metal-organic frameworks under pressure. For example, at $0.40 \mathrm{GPa}$ $\mathrm{Cd}(\mathrm{APP}){ }_{2} \mathrm{NO}_{3} \cdot \mathrm{NO}_{3}$ transforms between monoclinic phases, both of space-group symmetry $P 2_{1} / c$ (Półrolniczak et al., 2018) and $\mathrm{Co}_{2}\left(4,4^{\prime} \text {-bpy }\right)_{3}\left(\mathrm{NO}_{3}\right)_{4} \cdot x \mathrm{H}_{2} \mathrm{O}$ preserves its orthorhombic space group $C c c a$ at $p_{\mathrm{c}}=6 \mathrm{GPa}$ (Zhou et al., 2014), plus other known examples (Moggach et al., 2009; McKellar \& Moggach, 2015; Sobczak et al., 2018; Bhattacharyya et al., 2019).

Interestingly, the subtraction of the molecular volume of $\mathrm{ZnAsp} 2 \cdot 1.5 \mathrm{H}_{2} \mathrm{O}$ from that of $\mathrm{ZnAsp}_{2} \cdot 2 \mathrm{H}_{2} \mathrm{O}$ (denoted $\Delta V_{\mathrm{m}}$ ) should give the volume difference corresponding to half of the molecular volume of water [Fig. 6(b)]. The comparison of $\Delta V_{\mathrm{m}}$ with the volume of one $\mathrm{H}_{2} \mathrm{O}$ molecule in water and ices shows that there is more space in the pores than required for the accommodated water molecules, which explains the reason for the collapse of the pores. The work contribution to the Gibbs free energy at the transition in $\mathrm{ZnAsp}_{2} \cdot 1.5 \mathrm{H}_{2} \mathrm{O}$ is $3.1 \mathrm{~kJ} \mathrm{~mol}^{-1}$, compared with the work energy of $4.9 \mathrm{~kJ} \mathrm{~mol}^{-1}$ performed by the pressure to compress phase $\alpha$ from $0.1 \mathrm{MPa}$ to $0.8 \mathrm{GPa}$. The volume difference between $\mathrm{ZnAsp}_{2} \cdot 2 \mathrm{H}_{2} \mathrm{O}$ and $\mathrm{ZnAsp}_{2} \cdot 1.5 \mathrm{H}_{2} \mathrm{O}$ at $0.1 \mathrm{MPa}$ is consistent with the broad distribution of the volume of solvent water occurring in organic pharmaceuticals (Glasser, 2019).

\section{Practical implications}

The subtle balance of water content in these two hydrates of zinc aspartate $\left(\mathrm{ZnAsp}_{2}\right)$ has implications for its use as a pharmaceutical agent. The undesired release of water in tablets results in their degradation, as illustrated in the photograph in Fig. 7. These undesired effects can be avoided by using zinc aspartate in the form of the sesquihydrate, ZnAsp $2 \cdot 1.5 \mathrm{H}_{2} \mathrm{O}$, which is more stable and does not release or absorb water. The sesquihydrate can be obtained either by

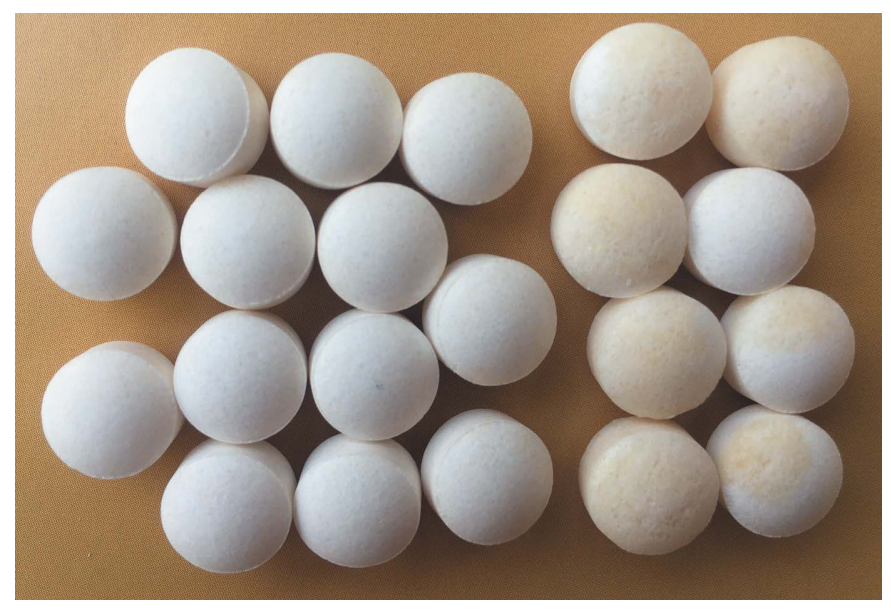

Figure 7

Tablets containing $\mathrm{ZnAsp} \mathrm{s}_{2} \cdot 2 \mathrm{H}_{2} \mathrm{O}$, some of which show clear signs of the release of water on the spontaneous transformation to $\mathrm{ZnAsp}_{2} \cdot 1.5 \mathrm{H}_{2} \mathrm{O}$ : in the eight tablets grouped on the right-hand side of the photograph the degradation is visible as a beige shade and swelling, which leads to their easy abrasion and crushing. drying the dihydrate precipitate obtained from aqueous solution, or by performing the crystallization under highpressure conditions. The high pressure of about $50 \mathrm{MPa}$ required for this purpose is technologically attainable for larger amounts of the sample, although it would require some safety measures. High-pressure crystallization could be more advantageous in terms of the time needed to obtain the required product. Thus the high-pressure crystallization of zinc aspartate can be regarded as a potential candidate for pharmaceutical applications of high pressure (see also Fabbiani et al., 2014).

\section{Conclusions}

We have established that the sesquihydrate $\mathrm{ZnAsp} 2 \cdot 1.5 \mathrm{H}_{2} \mathrm{O}$ is a stable form of the zinc aspartate complex $\left(\mathrm{ZnAsp}_{2}\right)$ under ambient conditions. We have shown that the precipitate obtained by crystallization from aqueous solution is the dihydrate, $\mathrm{ZnAsp}_{2} \cdot 2 \mathrm{H}_{2} \mathrm{O}$. The crystal structures of the sesquihydrate $\mathrm{ZnAsp}_{2} \cdot 1.5 \mathrm{H}_{2} \mathrm{O}$ and the dihydrate $\mathrm{ZnAsp} \cdot 2 \cdot 2 \mathrm{H}_{2} \mathrm{O}$ are closely related, despite their different space-group symmetries.

The most eminent feature of these structures is that they form frameworks containing channel pores that are occupied by water molecules. The water molecules can enter the pores of the sesquihydrate $\mathrm{ZnAsp}_{2} \cdot 1.5 \mathrm{H}_{2} \mathrm{O}$ when it is immersed in water, or leave the pores when the dihydrate $\mathrm{ZnAsp}_{2} \cdot 2 \mathrm{H}_{2} \mathrm{O}$ is exposed to the air. This transformation of the dihydrate into the sesquihydrate is a slow process, taking days or weeks depending on the volume of the sample, its container, the size of the crystal grains, the humidity of the air, ventilation, temperature and other relevant parameters. Thus it is recommended to check whether the transformation into the sesquihydrate has been completed before further processing, for example granulating or tabletting.

The sesquihydrate can also be obtained directly by highpressure crystallization. We found that an applied pressure as low as $50 \mathrm{MPa}$ favours crystallization of the sesquihydrate from aqueous solution at $298 \mathrm{~K}$.

The subtle isostructural phase transition in $\mathrm{ZnAsp}_{2} \cdot 1.5 \mathrm{H}_{2} \mathrm{O}$ illustrates the role of directional interactions in stabilizing porous structures. It can be postulated that the sesquihydrate is favoured by high pressure because it increases the close packing of molecules in the structure and destabilizes the directional interactions, like hydrogen bonds, which bind the water molecules into the pores. However, it is apparent from other reverse effects on other hydrates that the pressure effects are quite complex and depend on specific structural features.

It should be noted that all our attempts to recrystallize racemic $\mathrm{ZnAsp}_{2}$ hydrates never resulted in the separation of enantiomers. This negative result is consistent with the effect of pressure on other racemic mixtures of enantiomers reported so far (e.g. Jacques et al., 1994; Rietveld et al., 2011; Cai et al., 2013; Marciniak et al., 2014; Ostrowska et al., 2015; Wang et al., 2015; Ernst, 2018; Hochberg \& Cintas, 2018; Roszak \& Katrusiak, 2018). 


\section{Funding information}

The following funding is acknowledged: Narodowe Centrum Nauki (award No. UMO-2015/19/B/ST5/00262).

\section{References}

Andrzejewski, M., Olejniczak, A. \& Katrusiak, A. (2011). Cryst. Growth Des. 11, 4892-4899.

Anioła, M. \& Katrusiak, A. (2017). Cryst. Growth Des. 17, 3134-3141.

Azeem, M., Asif, M., Gui, D., Dong, L., Pei, C., Lu, P. \& Li, W. (2019). RSC Adv. 9, 13153-13158.

Bezacier, L., Journaux, B., Perrillat, J.-P., Cardon, H., Hanfland, M. \& Daniel, I. (2014). J. Chem. Phys. 141, 104505.

Bhattacharyya, S., Sobczak, S., Półrolniczak, A., Roy, S., Samanta, D., Katrusiak, A. \& Maji, T. K. (2019). Chem. Eur. J. 25, 6092-6097.

Boldyreva, E. V. (2003). J. Mol. Struct. 647, 159-179.

Boldyreva, E. V., Shakhtshneider, T. P., Ahsbahs, H., Sowa, H. \& Uchtmann, H. (2002). J. Therm. Anal. Calorim. 68, 437-452.

Bridgman, P. W. (1935). J. Chem. Phys. 3, 597-605.

Budzianowski, A. \& Katrusiak, A. (2004). High-Pressure Crystallographic Experiments with a CCD Detector. High-Pressure Crystallography, NATO Science Series, Vol. 140, edited by A. Katrusiak \& P. McMillan, pp. 101-112. Dordrecht: Springer.

Cai, W., Marciniak, J., Andrzejewski, M. \& Katrusiak, A. (2013). J. Phys. Chem. C, 117, 7279-7285.

Carrier, D. \& Wong, P. T. T. (1996). Chem. Phys. Lipids, 83, 141-152.

Dolomanov, O. V., Bourhis, L. J., Gildea, R. J., Howard, J. A. K. \& Puschmann, H. (2009). J. Appl. Cryst. 42, 339-341.

Ernst, K. H. (2018). Chimia, 72, 399-403.

Fabbiani, F. P. A., Allan, D. R., Dawson, A., David, W. I. F., McGregor, P. A., Oswald, I. D. H., Parsons, S. \& Pulham, C. R. (2003). Chem. Commun. 9, 3004-3005.

Fabbiani, F. P. A., Buth, G., Levendis, D. C. \& Cruz-Cabeza, A. J. (2014). Chem. Commun. 50, 1817-1819.

Fabbiani, F. P. A. \& Pulham, C. R. (2006). Chem. Soc. Rev. 35, 932942.

Figuiere, P., Ghelfenstein, M. \& Szwarc, H. (1975). Chem. Phys. Lett. 33, 99-103.

Glasser, L. (2019). Acta Cryst. B75, 784-787.

Groom, C. R., Bruno, I. J., Lightfoot, M. P. \& Ward, S. C. (2016). Acta Cryst. B72, 171-179.

Haase, H., Overbeck, S. \& Rink, L. (2008). Exp. Gerontol. 43, 394408.

Hochberg, D. \& Cintas, P. (2018). Phys. Chem. Chem. Phys. 20, 53055311.

Huskić, I., Novendra, N., Lim, D.-W., Topić, F., Titi, H. M., Pekov, I. V., Krivovichev, S. V., Navrotsky, A., Kitagawa, H. \& Friščić, T. (2019). Chem. Sci. 10, 4923-4929.

Jacques, J., Collet, A. \& Wilen, S. H. (1994). Enantiomers, Racemates and Resolutions. Malabar, Florida, USA: Krieger Publishing Company.

Katrusiak, A. (2001). J. Mol. Graphics Modell. 19, 363-367.

Katrusiak, A. (2008). Acta Cryst. A. 64, 135-148.

Kevenvolden, K. A. (1995). Org. Geochem. 23, 997-1008.

Kuhs, W. F., Finney, J. L., Vettier, C. \& Bliss, D. V. (1984). J. Chem. Phys. 81, 3612-3623.

Kuznetsov, A. Y., Pereira, Altair, S., Shiryaev, A. A., Haines, J., Dubrovinsky, L., Dmitriev, V., Pattison, P. \& Guignot, N. (2006). J. Phys. Chem. B, 110, 13858-13865.
Macrae, C. F., Sovago, I., Cottrell, S. J., Galek, P. T. A., McCabe, P., Pidcock, E., Platings, M., Shields, G. P., Stevens, J. S., Towler, M. \& Wood, P. A. (2020). J. Appl. Cryst. 53, 226-235.

Mao, H. K., Xu, J. \& Bell, P. M. (1986). J. Geophys. Res. 91, 46734676.

Marciniak, J., Andrzejewski, M., Cai, W. \& Katrusiak, A. (2014). J. Phys. Chem. C, 118, 4309-4313.

Martínez Casado, F. J., Ramos Riesco, M., Redondo, M. I., Choquesillo-Lazarte, D., López-Andrés, S. \& Cheda, J. A. R. (2011). Cryst. Growth Des. 11, 1021-1032.

McKellar, S. C. \& Moggach, S. A. (2015). Acta Cryst. B71, 587-607.

Merrill, L. \& Bassett, W. A. (1974). Rev. Sci. Instrum. 45, 290-294.

Moggach, S. A., Bennett, T. D. \& Cheetham, A. K. (2009). Angew. Chem. Int. Ed. 48, 7087-7089.

Neumann, M. A., van de Streek, J., Fabbiani, F. P. A., Hidber, P. \& Grassmann, O. (2015). Nat. Commun. 6, 7793-1-7.

Olejniczak, A. \& Katrusiak, A. (2010). CrystEngComm, 12, 25282532.

Ostrowska, K., Kropidłowska, M. \& Katrusiak, A. (2015). Cryst. Growth Des. 15, 1512-1517.

Oswald, I. D. H., Lennie, A. R., Pulham, C. R. \& Shankland, K. (2010). CrystEngComm, 12, 2533-2540.

Patyk-Kaźmierczak, E. \& Kaźmierczak, M. (2020). Acta Cryst. B76, 56-64.

Piermarini, G. J., Block, S., Barnett, J. D. \& Forman, R. A. (1975). J. Appl. Phys. 46, 2774-2780.

Półrolniczak, A., Sobczak, S. \& Katrusiak, A. (2018). Inorg. Chem. 57, 8942-8950.

Rietveld, I. B., Barrio, M., Tamarit, J. L., Do, B. \& Céolin, R. (2011). J. Phys. Chem. B, 115, 14698-14703.

Rigaku Oxford Diffraction (2015). CrysAlisPro. Rigaku Oxford Diffraction, Abingdon, UK.

Roohani, N., Hurrell, R., Kelishadi, R. \& Schulin, R. (2013). J. Res. Med. Sci. 18, 144-157.

Roszak, K. \& Katrusiak, A. (2018). Phys. Chem. Chem. Phys. 20, $5305-5311$.

Shankar, A. H. \& Prasad, A. S. (1998). Am. J. Clin. Nutr. 68, 447S463S.

Sheldrick, G. M. (2015a). Acta Cryst A71, 3-8.

Sheldrick, G. M. (2015b). Acta Cryst. C71, 3-8.

Sobczak, S., Chitnis, A., Andrzejewski, M., Mączka, M., Gohil, S., Garg, N. \& Katrusiak, A. (2018). CrystEngComm, 20, 5348-5355.

Tomkowiak, H. \& Katrusiak, A. (2018). J. Phys. Chem. C, 122, 5064 5070.

Tomkowiak, H., Olejniczak, A. \& Katrusiak, A. (2013). Cryst. Growth Des. 13, 121-125.

Van Valkenburg, A., Mao, H. K. \& Bell, P. M. (1971). Carnegie Institution Geophysical Laboratory, Annual Report of the Director, pp. 233-237.

Wang, K., Wang, Q., Yan, T. \& Lin, A. (2015). Chem. J. Chin. U. 36, 381-385.

Zakharov, B. A., Goryainov, S. V. \& Boldyreva, E. V. (2016a). CrystEngComm, 18, 5423-5428.

Zakharov, B. A., Gribov, P. A., Matvienko, A. A. \& Boldyreva, E. V. (2017). Z. Kristallogr. 232, 751-757.

Zakharov, B. A., Seryotkin, Y. V., Tumanov, N. A., Paliwoda, D., Hanfland, M., Kurnosov, A. V. \& Boldyreva, E. V. (2016b). RSC Adv. 6, 92629-92637.

Zhou, M., Wang, K., Men, Z., Sun, Ch., Li, Z., Liu, B., Zou, G. \& Zou, B. (2014). CrystEngComm, 16, 4084-4087.

Zieliński, W. \& Katrusiak, A. (2015). CrystEngComm, 17, 5468-5473. 